\title{
Music and Literature in Alejo Carpentier's Novel Baroque Concerto
}

\author{
Rodica Grigore ${ }^{1}$
}

Even after his original theory concerning the marvellous real became famous, once his novel El reino de este mundo (The Kingdom of This World) was published in 1949, the Cuban writer Alejo Carpentier continued to be preoccupied with certain aspects concerning different problems of magical realist discourse, relating it to the aesthetic domain of music and painting. The novelist tries thus to prove that the Latin American identity is perfectly expressed by those works of art and by those exquisite artists capable to catch the true nature of "The New World". Therefore, in his novel Concierto barroco (Baroque Concerto, 1974) he imagines a miraculous musical encounter bringing together composers and interpreters from different epochs and cultural spaces, in order to utter the ultimate truth about the individuality of a continent rather unknown to "The Old World" of Europe, but perfectly able to compete with its old values and artistic achievements. [Article copies available for a fee from The Transformative Studies Institute. E-mail address: journal@transformativestudies.org Website: http://www.transformativestudies.org (02020 by The Transformative Studies Institute. All rights reserved.]

KEYWORDS: Latin American Novel, Music, Painting, Marvellous Real, Magical Realist Discourse.

\footnotetext{
${ }^{1}$ Rodica Grigore, Ph.D., is senior lecturer in Comparative Literature at "Lucian Blaga" University of Sibiu, Romania. She is the author of several critical studies, such as: Despre cărţi şi alţi demoni [Of Books and Other Demons, 2002], Retorica măştilor în proza interbelică românească [The Rhetoric of Masks in Romanian Modern Fiction, 2005], Lecturi in labirint [Readings in the Labyrinth, 2007], Măşti, caligrafie, literatură [Masks, Calligraphy, Literature, 2011], In oglinda literaturii [In the Mirror of Literature, 2011], Meridianele prozei [Fiction's Meridians, 2013], Realismul magic in proza latinoamericană a secolului XX. [Magical Realism in Latin-American Fiction of the $20^{\text {th }}$ Century, 2015], Cărți, vise și identități în mișcare. Eseuri despre literatura contemporană [Books, Dreams and Changing Identities. Essays on the Contemporary Literature, 2018]. She has also translated into Romanian the essays of Octavio Paz, Children of the Mire, (2003/2017) and the poems of the Colombian writer Manuel Cortés Castañeda, Oglinda celuilalt [The Mirrored Other, 2006]. Between 2005 and 2012 she has been coordinating the anthology of The International Theatre Festival of Sibiu. She has published numerous essays and critical studies especially on modern literature in Romanian literary journals: "Observator Cultural", "Euphorion", "Viaţa Românească" etc. She is also known as a translator from English and Spanish. Address correspondence to: Rodica Grigore; e-mail: rodica.grigore@gmail.com.
} 